\title{
Recycled volatiles determine fertility of porphyry deposits in collisional settings
}

\author{
BO XU ${ }^{12}$, WILLIAM L. GRIFFIN ${ }^{2}$, SUZANNE Y. \\ O'REILLY', ZENG-QIAN HOU ${ }^{3}$, YONGJUN LU ${ }^{45}$, \\ ELENA BELOUSOVA ${ }^{2}$, ZHEN-YU CHEN ${ }^{3}$, JI-FENG \\ $\mathrm{XU}^{1}$ \\ ${ }^{1}$ State Key Laboratory of Geological Processes and Mineral Resources, \\ China University of Geosciences, Beijing 100083, China \\ ${ }^{2}$ ARC Centre of Excellence for Core to Crust Fluid Systems (CCFS) and \\ GEMOC, Macquarie University, NSW 2109, Australia \\ ${ }^{3}$ Chinese Academy of Geological Sciences, Beijing 100037, China \\ ${ }^{4}$ Geological Survey of Western Australia, 100 Plain Street, East Perth, \\ WA 6004, Australia \\ ${ }^{5}$ Centre for Exploration Targeting and CCFS, School of Earth Sciences, \\ The University of Western Australia, Crawley, WA 6009, Australia
}

The most important volatile elements controlling the transport of ore metals in magmatic fluids are $\mathrm{Cl}$ and $\mathrm{S}$; therefore their source and evolution are a major question for the genesis of porphyry deposits, especially in postsubduction settings. Here, we present geochemical data on apatite (860 major-element analyses, 627 minor-element analyses, 205 in-situ $\mathrm{Rb}-\mathrm{Sr}$ isotope analyses) from 12 porphyry systems across Iran, Tibet and western China, and from seven coeval barren localities within the postsubduction metallogenic belt. High rare-earth element contents, $\mathrm{V} / \mathrm{Y}$ and $(\mathrm{Ce} / \mathrm{Pb})_{\mathrm{N}}$ characterize apatite in fertile porphyries, reflecting a water-rich magma. Apatite from fertile suites also has higher chlorine and sulfur contents than those from coeval barren suites, revealing that high contents of magmatic $\mathrm{Cl}$ - and S-rich fluids are a prerequisite for the formation of magmatic-hydrothermal (porphyry) ores. The less radiogenic $\mathrm{Sr}$ isotopes of apatite from fertile magmas suggest that the elevated chlorine and sulfur reflect derivation of mantle-derived magmas from enriched sub-continental lithospheric mantle, metasomatised by previous oceanic subduction. Therefore, high-precision $\mathrm{Cl}, \mathrm{S}$, trace-element and $\mathrm{Sr}$ isotope data on apatite reveal a mantle-derived volatile-rich magma, and can distinguish fertile $(\mathrm{Cu} \pm \mathrm{Au} \pm$ Mo) from barren magmatic suites; this provides a useful tool for fingerprinting porphyry deposits. Analyzing the compositions of detrital apatites from an area with little geologic information or poor outcrop, such as the Tethyan belt, could assess whether the drainage source area is dominated by fertile systems, which could help focus exploration on prospective areas, especially in covered terranes. 